\title{
Enhanced Antibacterial Activity of Meropenem against Extensively Drug-Resistant Acinetobacter baumannii by Myrtaceae Plant Extracts ${ }^{\dagger}$
}

\author{
Dennapa SAELOH ${ }^{1,2, *}$, Monton VISUTTHI ${ }^{3}$, Marisa LEEHA ${ }^{4}$, \\ Surasak LIMSUWAN ${ }^{2,5}$ and Supayang Piyawan VORAVUTHIKUNCHAI ${ }^{2,4}$
}

\author{
${ }^{1}$ Faculty of Medical Technology, Prince of Songkla University, Songkhla 90110, Thailand \\ ${ }^{2}$ Natural Product Research Center of Excellence, Prince of Songkla University, \\ Songkhla 90110, Thailand \\ ${ }^{3}$ Biology Program, Faculty of Science and Technology, Nakhon Ratchasima Rajabhat University, \\ Nakhon Ratchasima 30000, Thailand \\ ${ }^{4}$ Division of Health and Applied Sciences, Faculty of Science, Prince of Songkla University, \\ Songkhla 90110, Thailand \\ ${ }^{5}$ Faculty of Traditional Thai Medicine, Prince of Songkla University, Songkhla 90110, Thailand
}

("Corresponding author's e-mail: dennapa.sa@psu.ac.th)

Received: 10 April 2019, Revised: 5 July 2019, Accepted: 21 August 2019

\begin{abstract}
Acinetobacter baumannii (A. baumannii) has been known as a major cause of nosocomial bacterial infections worldwide. The bacteria are increasingly associated with a broad spectrum of antibiotic resistance, and this has become a widespread concern in a variety of hospitals.Antibiotic development and alternative treatment have become priorities for the treatment of bacterial infections. This study investigated the efficacy of meropenem in combination with five ethanolic extracts of plants in Myrtaceae against extensively drug-resistant (XDR) A. baumannii. The resistant phenotype was previously determined by microdilution method. XDR-A. baumannii strains showed resistance to meropenem with the minimum inhibitory concentration (MIC) in a range of $16-128 \mu \mathrm{g} / \mathrm{mL}$, whereas the MIC value of all extracts, including Calistemon lancealatus, Eucalyptus citridora, Rhodomytus tomentasa, Syzygium cumini, and Xanthortemon chrysanthus, was over 1,000 $\mu \mathrm{g} / \mathrm{mL}$. Interestingly, all extracts potentiated the activity of the antibiotic by reducing the MIC values of the antibiotic. Xanthortemon chrysanthus extract displayed excellent synergism against the bacteria by decreasing the MIC value of the drug greater than 8 -fold. In addition, the extract, at concentrations of $31.25,62.5,125,250,500$, and 1,000 $\mu \mathrm{g} / \mathrm{mL}$, obviously increased the inhibitory effect of meropenem $(1 / 4 \times \mathrm{MIC})$ against $A$. baumannii. The percentage of bacterial growth inhibition by combination was $87.9,88.8,91.8,93.6,99.9$, and 100, respectively. The results supported that the extract could improve the activity of ineffective antibiotics against drugresistant pathogens.Therefore, the findings may serve as therapeutic options for XDR-A. baumannii infections in the future.
\end{abstract}

Keywords: Acinetobacter baumannii, Combination, Meropenem, Myrtaceae

${ }^{\dagger}$ Presented at the International Conferences on Biomedical Sciences and Medical Technology 2019: June 20 - 21, 2019

Walailak J Sci \& Tech 2020; 17(11): 1168-1176. 


\section{Introduction}

Acinetobacter baumannii (A. baumannii), an opportunistic nosocomial pathogen, is responsible for pneumonia, bacteremia, meningitis, and wound-surgery site infection. The bacteria are a cause of serious problems for global public healthcare, according to various drug resistances [1]. Carbapenems are the first-line drug for multidrug-resistant $A$. baumannii infection, but there is currently-emerging resistance to many antibiotics [2]. Carbapenem resistance is a hallmark of extensively drug-resistant phenotypes, being susceptible to only 1 or 2 antimicrobial categories [3]. Extensively drug-resistant $A$. baumannii (XDR- $A$. baumannii) is extremely difficult to treat and poses considerable infection control issues worldwide. The resistance leads to a 45 - $60 \%$ mortality rate in ICUs. In particular, ventilator-associated pneumonia has been found to be the cause of mortality up to $84.3 \%$ [4]. Colistin is a later-optional therapeutic for drugresistant $A$. baumannii infections. However, the adverse effects, such as nephrotoxicity, must be considered [5]. Combination antibiotic therapy has shown promise, such as meropenem-sulbactam and meropenem-colistin. Adverse effects such as nephrotoxicity and diarrhea remain [6]. Antibiotic development and alternative treatment with low toxicity are thus urgently needed to deal with these threats.

Searching for new antibiotics from natural resources, such as bacteria, fungi, and plants, has been receiving substantial attention. Among the sources of natural products, almost half of FDA-approved natural products have plant origins [7]. Due to their vast chemical diversity, plant metabolites have emerged as alternate antimicrobial agents and bioenhancers. Plants in Myrtaceae are the ninth largest plant family found in tropical areas and include more than 100 genera and 5,600 species. Myrtaceae species have been used in traditional medicine for the treatment of several diseases, such as gastrointestinal disorders, hemorrhagic issues, and infectious diseases [8]. It has been reported antimicrobial, anti-oxidant, and anti-inflammatory activities. Moreover, several extracts from Myrtaceae plants have been proven low toxicity in mouse models [9-11]. Considering these properties, there has been interest in developing it as an alternative agent.

In recent years, the use of bioactive plant extracts to increase antibiotic susceptibility of drugresistant bacteria has been of growing interest. Synergistic interaction between natural plants and antibiotics could convincingly reverse the antibiotic resistance of the bacteria and increase the efficiency of antibiotics. Moreover, small doses of synthetic medicines tend to decrease side-effects in pateints. The number of plant extracts acting in synergy with synthetic antibiotics against pathogens has been found. However, active extracts against Gram-negative bacteria, in particular XDR-A. baumannii, is in a minority [12]. Therefore, this study aimed to investigate the efficacy of meropenem in combination with extracts of Myrtaceae against XDR-A. baumannii.

\section{Materials and methods}

\section{Bacterial strains and culture conditions}

A. baumannii ATCC 19606 were used as a reference strain. Clinical bacterial isolates were taken from the Microbiology Unit, Department of Pathology, Songklanagarind Hospital, Thailand. Antibiotic sensitivity patterns of $A$. baumannii clinical isolates were assessed using disk diffusion susceptibility assay. The diameter of the inhibition zone around the antibiotic disk was measured and interpreted in accordance with the Clinical and Laboratory Standards Institute (CLSI) [13], Table S1 in the Supplementary Data.

\section{Medicinal plant materials}

Five Thai medicinal plants in the Myrtaceae family, Calistemon lancealatus (C. lancealatus), Eucalyptus citridora (E. citridora), Rhodomytus tomentasa (R. tomentosa), Syzygium cumini (S. cumini), and Xanthortemon chrysanthus (X. chrysanthus), were selected and collected in Nakhon Ratchasima province. Leaves were dried at $60{ }^{\circ} \mathrm{C}$ for 3 days and then extracted with $95 \%$ ethanol. The crude extracts were concentrated under reduced pressure in a rotary evaporator until complete dryness. The extracts were dissolved in dimethylsulfoxide before use. 


\section{Antimicrobial susceptibility and synergism testing}

Susceptibility testing was performed using a broth microdilution method following CLSI guidelines [13]. Minimal inhibitory concentrations (MICs) for meropenem and extracts were determined using resazurin. Subcultures were performed on Mueller-Hinton agar medium to estimate minimal bactericidal concentrations (MBCs).

Synergism testing of meropenem and extracts was assessed. 2-fold dilutions of the drug were carried out with the initial concentration as the MIC value. The concentration of the extracts was tested at $500 \mu \mathrm{g} / \mathrm{mL}$. MICs of combination were observed using resazurin. Interpretation was done by calculating the fractional inhibitory concentration index (FICI), according to the equation:

FICI $=\frac{\text { the MIC of drug and extract }}{\text { the MIC of drug. }}$

\section{Resistant modifying ability of the extract}

Resistant modifying ability of the extract was observed by growth inhibition assays. A. baumannii ATCC 19606 was grown in a combination of meropenem at a concentration of $1 / 4 \times \mathrm{MIC}$, and $X$. chrysanthus at varying concentrations. After $16 \mathrm{~h}$ of incubation, bacterial cells were enumerated using a drop plate method. The percentage of growth inhibition was calculated from the following equation:

$\%$ growth inhibition $=\frac{100 \times(\text { No.control }- \text { No.test })}{\text { No.control }}$

No. control is the number of bacterial cells treated with meropenem, and No. test is number of bacterial cells treated with meropenem and plant extracts. Statistical analysis was performed by Student's paired t-test, with a 2 tailed distribution. All tests were conducted with a significance level of $0.01(p<$ $0.01)$.

\section{Results}

The minimum inhibitory concentration (MIC) of meropenem was in a range of $16-128 \mu \mathrm{g} / \mathrm{mL}$ and the minimum bactericidal concentration (MBC) was in a range of $32-256 \mu \mathrm{g} / \mathrm{mL}$ (Table 1). Meanwhile, the MIC value of all extracts of C. lancealatus, E. citridora, $R$. tomentasa, S. cumini, and X. chrysanthus was over $1,000 \mu \mathrm{g} / \mathrm{mL}$. In combination with meropenem, all extracts showed synergistic activity and reduction of the MIC values of the antibiotic by various folds (Table 2). Interestingly, $X$. chrysanthus extract displayed excellent synergism against the bacteria by a decrease in the MIC value of the drug greater than 8-folds (Table 3). Furthermore, the extract, at concentrations of 31.25, 62.5, 125, 250, 500, and $1,000 \mu \mathrm{g} / \mathrm{mL}$, notably increased the inhibitory effect of meropenem (1/4×MIC) against $A$. baumannii. Combination therapy illustrated significant reduction $(p<0.01)$ of bacterial growth compared to meropenem alone (Table 4). The percentage of bacterial growth inhibition by combination was 87.9, 88.8, 91.8, 93.6, 99.9, and 100, respectively (Figure 1).

Table 1 Minimal inhibitory concentration (MIC) and minimal bactericidal concentration (MBC) of meropenem on XDR-A. baumannii.

\begin{tabular}{lllllll}
\hline $\begin{array}{l}\text { Concentration } \\
\text { of meropenem }\end{array}$ & $\begin{array}{l}\text { ATCC } \\
\mathbf{1 9 6 0 6}\end{array}$ & Clinical 1 & Clinical 2 & Clinical 3 & Clinical 4 & Clinical 5 \\
\hline $\mathrm{MIC}(\mu \mathrm{g} / \mathrm{mL})$ & 32 & 128 & 128 & 64 & 32 & 64 \\
$\mathrm{MBC}(\mu \mathrm{g} / \mathrm{mL})$ & 64 & 128 & $>256$ & 128 & 64 & 64 \\
\hline
\end{tabular}


http://wjst.wu.ac.th

Table 2 Effects of meropenem in combination with extracts against XDR-A. baumannii.

\begin{tabular}{lllllll}
\hline \multirow{2}{*}{ Extracts } & \multicolumn{6}{c}{ Concentration of meropenem (fold reduction) } \\
\cline { 2 - 7 } & $\begin{array}{l}\text { ATCC } \\
\mathbf{1 9 6 0 6}\end{array}$ & Clinical 1 & Clinical 2 & Clinical 3 & Clinical 4 & Clinical 5 \\
\hline C. lancealatus & $8(4)$ & $32(4)$ & $\leq 16(\geq 8)$ & $32(2)$ & $16(2)$ & $64(0)$ \\
E. citridora & $8(4)$ & $32(4)$ & $\leq 16-32(\geq$ & $16-32(\geq$ & $16(2)$ & $32(2)$ \\
R. tomentasa & $8(4)$ & $32(4)$ & $\leq 16(\geq 8)$ & $16-32(\geq 2)$ & $16(2)$ & $64(2)$ \\
S. cumini & $16(2)$ & $32(4)$ & $32(4)$ & $32(2)$ & $32(0)$ & $\leq 8-16(\geq 4)$ \\
X. chrysanthus & $8(4)$ & $\leq 16(\geq 8)$ & $\leq 16(\geq 8)$ & $\leq 8-16(\geq 2)$ & $16(2)$ & $\leq 8-32(\geq 2)$ \\
Meropenem & 32 & 128 & 128 & 64 & 32 & 64 \\
\hline
\end{tabular}

Table 3 Fractional inhibitory concentration index (FICI) of combination against XDR-A. baumannii.

\begin{tabular}{lllllll}
\hline \multirow{2}{*}{ Extracts } & \multicolumn{7}{c}{ Fractional inhibitory concentration index (FICI) } \\
\cline { 2 - 7 } & $\begin{array}{l}\text { ATCC } \\
\mathbf{1 9 6 0 6}\end{array}$ & Clinical 1 & Clinical 2 & Clinical 3 & Clinical 4 & Clinical 5 \\
\hline C. lancealatus & $0.25(\mathrm{~S})$ & $0.25(\mathrm{~S})$ & $\leq 0.125-0.25(\mathrm{~S})$ & $0.5(\mathrm{~S})$ & $0.5(\mathrm{~S})$ & $1(\mathrm{I})$ \\
E. citridora & $0.25(\mathrm{~S})$ & $0.25(\mathrm{~S})$ & $0.25(\mathrm{~S})$ & $0.5(\mathrm{~S})$ & $0.5(\mathrm{~S})$ & $0.5(\mathrm{~S})$ \\
R. tomentasa & $0.25(\mathrm{~S})$ & $0.25(\mathrm{~S})$ & $\leq 0.125(\mathrm{~S})$ & $0.5(\mathrm{~S})$ & $0.5(\mathrm{~S})$ & $1(\mathrm{I})$ \\
S. cumini & $0.5(\mathrm{~S})$ & $0.25(\mathrm{~S})$ & $0.25(\mathrm{~S})$ & $0.5(\mathrm{~S})$ & $1(\mathrm{I})$ & $0.25(\mathrm{~S})$ \\
X. chrysanthus & $0.25(\mathrm{~S})$ & $\leq 0.125(\mathrm{~S})$ & $\leq 0.125(\mathrm{~S})$ & $\leq 0.25(\mathrm{~S})$ & $0.5(\mathrm{~S})$ & $0.5(\mathrm{~S})$ \\
\hline
\end{tabular}

FICI: < 1; Synergistic (S), 1 - 4; Indifference (I), > 4; Antagonistic (A)

Table 4 Effects of a combination of meropenem $(1 / 4 \times \mathrm{MIC})$ and $X$. chrysanthus extract on the growth of A. baumannii ATCC 19606.

\begin{tabular}{|c|c|c|}
\hline Combination & $\begin{array}{c}\text { Number of bacteria } \\
\left(\times 10^{4} \mathrm{cfu} / \mathrm{mL}\right)\end{array}$ & $p$-value \\
\hline $1 / 4 \times$ MIC meropenem & $37888 \pm 2524$ & - \\
\hline $1 / 4 \times$ MIC meropenem $+31.25 \mu \mathrm{g} / \mathrm{mL} X$. chrysanthus & $4600 \pm 624$ & 0.0011 \\
\hline $1 / 4 \times$ MIC meropenem $+62.5 \mu \mathrm{g} / \mathrm{mL} X$. chrysanthus & $4244 \pm 568$ & 0.0012 \\
\hline $1 / 4 \times$ MIC meropenem $+125 \mu \mathrm{g} / \mathrm{mL} X$. chrysanthus & $3111 \pm 192$ & 0.0016 \\
\hline $1 / 4 \times$ MIC meropenem $+250 \mu \mathrm{g} / \mathrm{mL} X$. chrysanthus & $2400 \pm 458$ & 0.0021 \\
\hline $1 / 4 \times$ MIC meropenem $+500 \mu \mathrm{g} / \mathrm{mL} X$. chrysanthus & $28 \pm 4$ & 0.0015 \\
\hline $1 / 4 \times$ MIC meropenem $+1000 \mu \mathrm{g} / \mathrm{mL} X$. chrysanthus & 0 & 0.0015 \\
\hline
\end{tabular}

${ }^{a}$ Values were means \pm standard deviations.

${ }^{\mathrm{b}} p$-values compared combination therapy and meropenem alone. 
http://wjst.wu.ac.th

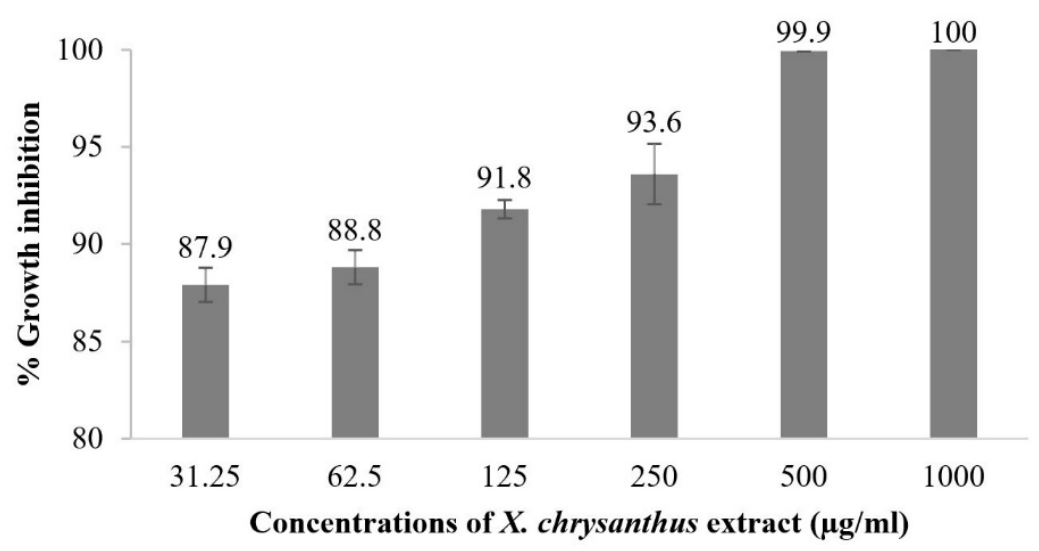

Figure 1 Bacterial growth inhibition of a combination of meropenem $(1 / 4 \times \mathrm{MIC})$ and $X$. chrysanthus extract against $A$. baumannii ATCC 19606.

\section{Discussion}

Acinetobacter baumannii is an opportunistic bacterial pathogen generally associated with severe nosocomial infections. Increasing multidrug resistance among Acinetobacter isolates to most of the currently available antibiotic agents has been documented $[1,2,4]$. The carbapenem class of $\beta$-lactam antibiotics, including meropenem, has been used as the last-line treatment for infections with multidrugresistant $A$. baumannii [14]. However, during the last few years, a significant increase in the prevalence of carbapenem-resistant $A$. baumannii strains has been reported $[15,16]$. The incidence has dramatically become a serious problem that limits the therapeutic options for A. baumannii infection [15-17]. Considering the bacteria resistance to currently available antimicrobial agents, the development or discovery of new substances, as well as drug combinations, against multidrug-resistant $A$. baumannii infection are essential.

Several plants, such as extracts from Anthocleista schweinfurthii, Nauclea pobeguiinii, and Zehneria scobra, have been reported to have antibacterial activity and found to have antibiotic-resistance modifying activity against Gram-negative multi-drug resistant bacteria [18,19]. Five Myrtaceae plant extracts have been previously reported to have antibacterial activity, particularly Gram-positive bacteria [20]. This study demonstrated that all ethanol extracts had no antibacterial activity against XDR- $A$. baumannii Gram-negative bacteria. However, the crude extracts could enhance XDR-A. baumannii sensitivity to meropenem. Therefore, the extracts might have vital composition to interrupt the drugresistant mechanisms of the bacteria. Numerous plant-derived compounds with antibiotic-modulation activity against drug-resistant bacteria have been noted to inhibit antibacterial resistance in a variety of mechanisms [21,22]. Guttiferone-A and 7-epiclusianone, isolated from the fruits of Garcinia brasiliensis, could reverse resistance to ß-lactams by inhibiting ß-lactamase [23], while tannic acid was found to be a drug-resistant modifying agent through the inhibition of carbapenemase [24].

XDR-A. baumannii has various drug-resistant mechanisms, including the production of $\beta$ lactamases, the modification of penicillin-binding proteins, and the decrease of porin permeability. Moreover, the presence of efflux pumps and MDR-proteins in the bacterial cells significantly contribute to both intrinsic and acquired resistance to antibiotics $[25,26]$. Plant-derived compounds have resulted in the inhibition of efflux pumps in A. baumannii [27] such as trans-cinnamaldehyde, eugenol [28], ellagic acid, tannic acid [21], and berberine [29]. In this study, A. baumannii ATCC 19606 was used as a meropenem-resistant reference strain [30]. The common antibiotic resistant mechanism of the strain is a multidrug efflux system using resistance-nodulation-division (RND) efflux pumps, specifically Gramnegative microorganisms [31]. In addition, the tested clinical isolates were representative of the absence of $b l a_{\mathrm{OXA}-23}$, the carbapenemase producing gene [32]. The strains might resist meropenem via efflux 
pump systems. According to the prominent synergistic effect between $X$. chrysanthus extract and meropenem against the bacteria, the plant extract might play a role as an efflux pump inhibitor, leading to improvement in the activity of antibiotics. However, the mechanisms of $X$. chrysanthus extract on bacterial cells should be further investigated. Furthermore, individual compounds of the crude extract should be identified to find the major active compounds with greatest potency.

\section{Conclusions}

Myrtaceae plant extract, especially $X$. chrysanthus extract, could improve the activity of ineffective meropenem against drug-resistant pathogens. The drug resistance reversal potential of the extract has been reported for the first time. Therefore, the findings may serve as therapeutic options for XDR- $A$. baumannii infections in the future. In addition, the active constituents of the promising plant should be further investigated.

\section{Acknowledgements}

This work was supported by the Research Fund, Faculty of Medical Technology, Prince of Songkla University, fiscal year 2017 (grant number MET601520S) and the Thailand Research Fund Senior Research Scholar (grant number RTA6180006).

\section{References}

[1] C Willyard. The drug-resistant bacteria that pose the greatest health threats. Nature News 2017; 543, 15 .

[2] D Wong, TB Nielsen, RA Bonomo, P Pantapalangkoor, B Luna and B Spellberg. Clinical and pathophysiological overview of Acinetobacter infections: A century of challenges. Clin. Microbiol. Rev. 2017; 30, 409-47.

[3] AP Magiorakos, A Srinivasan, R Carey, Y Carmeli, M Falagas, C Giske, S Harbarth, J Hindler, G Kahlmeter and B Olsson-Liljequist. Multidrug-resistant, extensively drug-resistant and pandrugresistant bacteria: An international expert proposal for interim standard definitions for acquired resistance. Clin. Microbiol. Infect. 2012; 18, 268-81.

[4] ES Özgür, ES Horasan, K Karaca, G Ersöz, SN Atış and A Kaya. Ventilator-associated pneumonia due to extensive drug-resistant Acinetobacter baumannii: Risk factors, clinical features, and outcomes. Am. J. Infect. Control. 2014; 42, 206-8.

[5] AO Javan, S Shokouhi and Z Sahraei. A review on colistin nephrotoxicity. Eur. J. Clin. Pharmacol. 2015; 71, 801-10.

[6] M Paul, GL Daikos, E Durante-Mangoni, D Yahav, Y Carmeli, YD Benattar, A Skiada, R Andini, $\mathrm{N}$ Eliakim-Raz and A Nutman. Colistin alone versus colistin plus meropenem for treatment of severe infections caused by carbapenem-resistant Gram-negative bacteria: An open-label, randomised controlled trial. Lancet Infect. Dis. 2018; 18, 391-400.

[7] E Patridge, P Gareiss, MS Kinch and D Hoyer. An analysis of FDA-approved drugs: Natural products and their derivatives. Drug Discov. Today 2016; 21, 204-7.

[8] MM Cascaes, GMSP Guilhon, EHdA Andrade, MGB Zoghbi and LdS Santos. Constituents and pharmacological activities of Myrcia (Myrtaceae): A review of an aromatic and medicinal group of plants. Int. J. Mol. Sci. 2015; 16, 23881-904.

[9] E Al-Sayed and RN El-Naga. Protective role of ellagitannins from Eucalyptus citriodora against ethanol-induced gastric ulcer in rats: Impact on oxidative stress, inflammation and calcitonin-gene related peptide. Phytomedicine 2015; 22, 5-15.

[10] PE Bitencourt, LM Ferreira, LO Cargnelutti, L Denardi, A Boligon, M Fleck, R Brandão, ML Athayde, L Cruz and RA Zanette. A new biodegradable polymeric nanoparticle formulation containing Syzygium cumini: Phytochemical profile, antioxidant and antifungal activity and in vivo toxicity. Ind. Crop. Prod. 2016; 83, 400-7. 
http://wjst.wu.ac.th

[11] S El-Refai, A Atia and S Mahmoud. Effects of Callistemon citrinus aqueous extract on prepatent and patent infections with Schistosoma mansoni in experimentally infected mice. J. Helminthol. 2018; 93, 1-10.

[12] S Chanda and K Rakholiya. Combination Therapy: Synergism between Natural Plant Extracts and Antibiotics against Infectious Diseases. In: A Mendez-Vilas (Ed.). Science against Microbial Pathogens: Communicating Current Research and Technological Advances. Microbiolology Book Series, Badajos, Spain, 2011, p. 520-9.

[13] CLSI. Performance Standards for Antimicrobial Susceptibility Testing. $27^{\text {th }}$ eds. CLSI Supplement M100, Wayne, PA, 2017.

[14] R Zarrilli, M Giannouli, F Tomasone, M Triassi and A Tsakris. Carbapenem resistance in Acinetobacter baumannii: The molecular epidemic features of an emerging problem in health care facilities. J. Infect. Dev. Ctries 2009; 3, 335-41.

[15] E Righi, AM Peri, PN Harris, AM Wailan, M Liborio, SW Lane and DL Paterson. Global prevalence of carbapenem resistance in neutropenic patients and association with mortality and carbapenem use: Systematic review and meta-analysis. J. Antimicrob. Chemother. 2017; 72, 668-77.

[16] SS Kadri, J Adjemian, YL Lai, AB Spaulding, E Ricotta, DR Prevots, TN Palmore, C Rhee, M Klompas and JP Dekker. Difficult-to-treat resistance in Gram-negative Bacteremia at 173 US Hospitals: Retrospective cohort analysis of prevalence, predictors, and outcome of resistance to all first-line agents. Clin. Infect. Dis. 2018; 67, 1803-14.

[17] X Li, L Wang, XJ Zhang, Y Yang, WT Gong, B Xu, YQ Zhu and W Liu. Evaluation of meropenem regimens suppressing emergence of resistance in Acinetobacter baumannii with human simulated exposure in an in vitro intravenous infusion hollow-fiber infection model. J. Antimicrob. Chemother. 2014; 58, 6773-81.

[18] DE Djeussi, JA Noumedem, BT Ngadjui and V Kuete. Antibacterial and antibiotic-modulation activity of six Cameroonian medicinal plants against Gram-negative multi-drug resistant phenotypes. BMC Compl. Alternative Med. 2016; 16, 124-33.

[19] JA Seukep, LP Sandjo, BT Ngadjui and V Kuete. Antibacterial and antibiotic-resistance modifying activity of the extracts and compounds from Nauclea pobeguinii against Gram-negative multi-drug resistant phenotypes. BMC Compl. Alternat. Med. 2016; 16, 193-201.

[20] M Visutthi. Anti-staphylococcal screening of selected Thai medicinal plants from Nakhon Ratchasima province. Suranaree J. Sci. Technol. 2016; 23, 109-14.

[21] S Chusri, I Villanueva, SP Voravuthikunchai and J Davies. Enhancing antibiotic activity: A strategy to control Acinetobacter infections. J. Antimicrob. Chemother. 2009; 64, 1203-11.

[22] A Duarte, S Ferreira, F Silva and F Domingues. Synergistic activity of coriander oil and conventional antibiotics against Acinetobacter baumannii. Phytomedicine 2012; 19, 236-8.

[23] NL Maia, M de Barros, LL de Oliveira, SA Cardoso, MH dos Santos, FA Pieri, TC Ramalho, EF da Cunha and MA Moreira. Synergism of plant compound with traditional antimicrobials against Streptococcus spp. isolated from bovine mastitis. Front. Microbiol. 2018; 9, 1-10.

[24] AM Somboro, JO Sekyere, DG Amoako, HM Kumalo, R Khan, LA Bester and SY Essack. In vitro potentiation of carbapenems with tannic acid against carbapenemase-producing enterobacteriaceae: Exploring natural products as potential carbapenemase inhibitors. J. Appl. Microbiol. 2019; 126, 452-67.

[25] PB Savage. Multidrug-resistant bacteria: Overcoming antibiotic permeability barriers of Gramnegative bacteria. Ann. Med. 2001; 33, 167-71.

[26] J Vila, S Martí and J Sanchez-Céspedes. Porins, efflux pumps and multidrug resistance in Acinetobacter baumannii. J. Antimicrob. Chemother. 2007; 59, 1210-5.

[27] K Lewis and FM Ausubel. Prospects for plant-derived antibacterials. Nat. Biotechnol. 2006; 24 , 1504-7.

[28] DP Karumathil, MS Nair, J Gaffney, A Kollanoor-Johny and K Venkitanarayanan. Transcinnamaldehyde and eugenol increase Acinetobacter baumannii sensitivity to beta-lactam antibiotics. Front. Microbiol. 2018; 9, 1-10. 
http://wjst.wu.ac.th

[29] AR Ball, G Casadei, S Samosorn, JB Bremner, FM Ausubel, TI Moy and K Lewis. Conjugating berberine to a multidrug resistance pump inhibitor creates an effective antimicrobial. ACS Chem. Biol. 2006; 1, 594-600.

[30] JR Lenhard, JB Bulitta, TD Connell, N King-Lyons, CB Landersdorfer, SE Cheah, V Thamlikitkul, BS Shin, G Rao and PN Holden. High-intensity meropenem combinations with polymyxin B: New strategies to overcome carbapenem resistance in Acinetobacter baumannii. J. Antimicrob. Chemother. 2016; 72, 153-65.

[31] D Fernando and A Kumar. Growth phase-dependent expression of RND efflux pump-and outer membrane porin-encoding genes in Acinetobacter baumannii ATCC 19606. ACS Infect. Dis. 2011; 67, 569-72.

[32] Y Zhang, Z Li, X He, F Ding, W Wu, Y Luo, B Fan and H Cao. Overproduction of efflux pumps caused reduced susceptibility to carbapenem under consecutive imipenem-selected stress in Acinetobacter baumannii. Infect. Drug. Resist. 2017; 11, 457-67. 


\section{Supplementary data}

Table S1 Antibiotic sensitivity patterns of Acinetobacter baumannii isolates.

\begin{tabular}{|c|c|c|c|c|c|c|}
\hline \multirow[b]{2}{*}{ Antibiotic class } & \multirow[b]{2}{*}{ Antibiotic } & \multicolumn{5}{|c|}{ Acinetobacter baumannii } \\
\hline & & $\begin{array}{l}\text { clinical } \\
1\end{array}$ & $\begin{array}{l}\text { clinical } \\
2\end{array}$ & $\begin{array}{l}\text { clinical } \\
3\end{array}$ & $\begin{array}{l}\text { clinical } \\
4\end{array}$ & $\begin{array}{l}\text { clinical } \\
5\end{array}$ \\
\hline \multirow{3}{*}{ aminoglycosides } & amikacin & $\mathrm{R}$ & $\mathrm{S}$ & $\mathrm{R}$ & $\mathrm{R}$ & $\mathrm{R}$ \\
\hline & gentamicin & $\mathrm{R}$ & $\mathrm{R}$ & $\mathrm{R}$ & $\mathrm{R}$ & $\mathrm{S}$ \\
\hline & netilmicin & $\mathrm{R}$ & $\mathrm{R}$ & $\mathrm{R}$ & $\mathrm{R}$ & $\mathrm{R}$ \\
\hline \multirow{3}{*}{ carbapenems } & imipenem & $\mathrm{R}$ & $\mathrm{R}$ & $\mathrm{R}$ & $\mathrm{R}$ & $\mathrm{R}$ \\
\hline & meropenem & $\mathrm{R}$ & $\mathrm{R}$ & $\mathrm{R}$ & $\mathrm{R}$ & $\mathrm{R}$ \\
\hline & ertapenem & $\mathrm{R}$ & $\mathrm{R}$ & $\mathrm{R}$ & $\mathrm{R}$ & $\mathrm{R}$ \\
\hline \multirow{5}{*}{ cephalosporins } & cefotaxime & $\mathrm{R}$ & $\mathrm{R}$ & $\mathrm{R}$ & $\mathrm{R}$ & $\mathrm{R}$ \\
\hline & cefoxitin & $\mathrm{R}$ & $\mathrm{R}$ & $\mathrm{R}$ & $\mathrm{R}$ & $\mathrm{R}$ \\
\hline & ceftriaxone & $\mathrm{R}$ & $\mathrm{R}$ & $\mathrm{R}$ & $\mathrm{R}$ & $\mathrm{R}$ \\
\hline & cefuroxime & $\mathrm{R}$ & $\mathrm{R}$ & $\mathrm{R}$ & $\mathrm{R}$ & $\mathrm{R}$ \\
\hline & sulperazone & I & $\mathrm{S}$ & $\mathrm{R}$ & $\mathrm{R}$ & $\mathrm{S}$ \\
\hline \multirow{2}{*}{ fluoroquinolones } & ciprofloxacin & $\mathrm{R}$ & $\mathrm{R}$ & $\mathrm{R}$ & $\mathrm{R}$ & $\mathrm{R}$ \\
\hline & norfloxacin & $\mathrm{R}$ & $\mathrm{S}$ & $\mathrm{R}$ & $\mathrm{R}$ & $\mathrm{R}$ \\
\hline \multirow{2}{*}{$\begin{array}{l}\text { penicillin }+ \\
\beta \text {-lactamase inhibitor }\end{array}$} & ampicillin & $\mathrm{R}$ & $\mathrm{R}$ & $\mathrm{R}$ & $\mathrm{R}$ & $\mathrm{R}$ \\
\hline & $\begin{array}{l}\text { tazocin (piperacillin/ } \\
\text { tazobactam) }\end{array}$ & $\mathrm{R}$ & $\mathrm{R}$ & $\mathrm{R}$ & $\mathrm{R}$ & $\mathrm{R}$ \\
\hline polymyxins & colistin & $\mathrm{S}$ & $\mathrm{S}$ & $\mathrm{R}$ & $\mathrm{S}$ & $\mathrm{S}$ \\
\hline sulfonamides & $\begin{array}{l}\text { co-trimoxazole } \\
\text { (trimethoprim/ } \\
\text { sulfamethoxazole) }\end{array}$ & $\mathrm{R}$ & $\mathrm{R}$ & $\mathrm{S}$ & $\mathrm{R}$ & $\mathrm{R}$ \\
\hline tetracycline & tigecycline & $\mathrm{R}$ & $\mathrm{S}$ & $\mathrm{R}$ & I & I \\
\hline
\end{tabular}

